\title{
"Now with Ultraviolent Zombie Mayhem!" The Neo-Victorian Novel-as-Mashup and the Limits of Postmodern Irony
}

\author{
Megen de Bruin-Molé
}

\begin{abstract}
This article situates the novel-as-mashup, first popularised by Seth Grahame-Smith's Pride and Prejudice and Zombies (2009), within twenty-firstcentury neo-Victorianism. Using several key examples of these mashup texts, it embarks on a discussion of postmodernism's ironic nostalgia, exploring the limits of such irony through questions of hermeneutics and ethics that are currently relevant in the field of neo-Victorian studies. Is it possible to find any stable meaning (or meaningful irony) in a text that is made up of other texts? What happens when texts are wilfully or inadvertently misread, and how do we approach instances where misreading causes harm, or reproduces problematic ideologies? Can texts that do not use the past seriously still be ironic, and if not, what does this mean for commercial, parodical genres like the novel-as-mashup?
\end{abstract}

Keywords: appropriation, camp, ethics, hermeneutics, irony, monsters, nostalgia, parody, postmodernism, zombies.

\author{
$* * * * *$ \\ "Literary Mashups Meet Tentacles. Has All Of Western Literature \\ Been Leading Up To This [?]" (Anders 2009)
}

How 'seriously' or un-ironically should a text take its relationship with the past in order to warrant the attention of academics studying historical fiction and neo-Victorianism? In February 2009, the internet was abuzz with a pop culture trend that would raise this and many other questions: the literary novel-as-mashup. Carolyn Kellogg sees the novel-as-mashup as distinct from other postmodern literary experiments, in that it does more than recycle characters, settings, or plot points from existing works (Kellogg 2009: para. 3). Instead, it appropriates an author's actual words and sentences in their entirety, 
making minor changes throughout the text to create a new, if fundamentally similar story. Although many people have used the mashup technique in the past, particularly in the twenty-first century, ${ }^{1}$ Pride and Prejudice and Zombies was the first written text to employ this technique so extensively, combining $85 \%$ of Jane Austen's 1813 novel Pride and Prejudice with 15\% "ultraviolent zombie mayhem" (Grahame-Smith and Austen 2009: 3, inside cover). Though successive examples of the novel-as-mashup have tended to supplement their appropriated texts with a much higher percentage of new content, they are still often accused of being Frankensteinian at best, and blatantly plagiarist at worst. These split opinions highlight the ambiguity of the postmodern cannibalisation process in which the novel-as-mashup is arguably engaged. They also confront us with the way both adaptation studies and neo-historical scholarship address questions of faithfulness and ethical appropriation, without always considering how literary irony may be misread and misused.

The novel-as-mashup's commercialism and superficiality potentially defines it as something Christian Gutleben calls "nostalgic postmodernism" (Gutleben 2001). In his 2001 monograph, Gutleben discusses how twentieth and twenty-first-century "retro-Victorian" (or neo-Victorian novels) portray the nineteenth-century past in which they situate themselves (Gutleben 2001: 5). His analysis of neoVictorian fiction is split, broadly speaking, into two chronological phases of revisionist texts. The first phase contains those early neoVictorian texts that resist nostalgia, where "ironic recycling of the myth-laden Victorian novel was at the avant-garde of postmodernism in Britain" (Gutleben 2001: 120). The second phase, "thirty years later, after many more rewritings of myths, traditions and genres", finds the neo-Victorian succumbing to nostalgia and realist tendencies, with the consequence that "the same principle of modernizing tradition appears inevitably less progressive" (Gutleben 2001: 120). From this perspective, the novel-as-mashup could be seen as the culmination of a process of cultural regression. It is highly unlikely that anyone would regard the novel-as-mashup as 'realist' given the fantastical monsters that populate its pages, but the novel-as-

\footnotetext{
${ }^{1}$ For further academic analysis of the recent fascination with mashups across various media, see Lessig 2008; Sonvilla-Weiss 2010; Sinnreich 2010; McLeod and DiCola 2011, and Navas and Gallagher 2015.
} 
mashup most certainly can be (and has been) accused of having nostalgic tendencies, turning to the past as either an escape from the present or as a calculated marketing strategy. Indeed, although Gutleben's use of the term 'progressive' here is potentially problematic for its emphasis on certain highbrow texts above the middlebrow and lowbrow, his point about the cultural shift away from postmodernism's avant-garde irony is very germane. Postmodern irony may have outlived its usefulness.

As one critic writes of the novel-as-mashup genre, "[i]t's hard to say, in the end, if this is an homage, an exploitation, a deconstruction, or just a 300-page parlor trick" (Anderson 2009: para. 5). This functional ambiguity is part of the genre's appeal for many readers, as well as the source of its potential irony and humour. In other words, as Susan Sontag puts it, camp "is beautiful because it is awful" (Sontag 1969: 293). The novel-as-mashup aptly fits Sontag's description. Its success both as a commercial product and within fan communities proves its allure, though negative responses from many literary critics suggest that its intentional awfulness (rather than traditionally laudable aesthetic qualities) may best explain its attractions. It belongs to the realm of camp, which, as Stephen Linstead argues, "deploys outrageous kitsch with reflexive irony in order to draw attention to the artificiality of boundaries" (Linstead 2002: 666). In the case of the novel-as-mash-up, not only are the boundaries between texts scrutinised, but also those between creativity and reproduction, originality and plagiarism.

Ironically, Seth Grahame-Smith's (or Grahame-Smith and Austen's) Pride and Prejudice and Zombies (2009) became a publishing success before anyone had even read a word of the text. A single blogger came across the image for the cover - a mashup in itself, featuring a painting by William Beechey that had been digitally altered by Doogie Horner (see Figure 1) - and that image, combined with the book's title, sparked an internet phenomenon. 


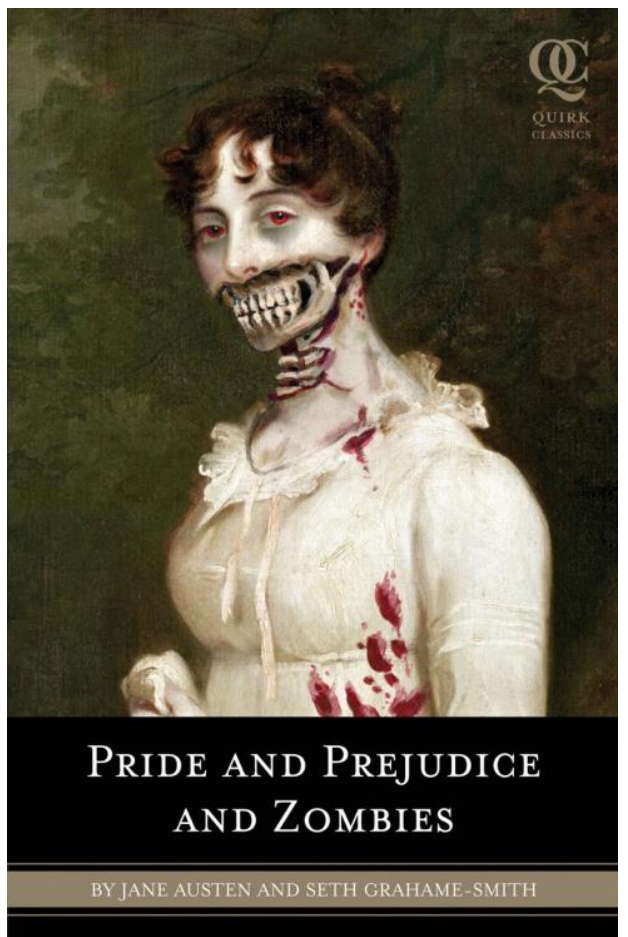

Figure 1. Front cover of Pride and Prejudice and Zombies, () and TM 2009 by Quirk Productions, Inc. Image courtesy the Bridgman Art Library. Zombification by Doogie Horner. Reprinted with permission from Quirk Books.

Originally scheduled for July release, the publication date for Pride and Prejudice and Zombies was pushed forward by three months to April in order to capitalise on the publicity. Two months before the book was even released, it had been mentioned on more than a thousand different websites (Deahl 2009: para. 7). As of 2013 it had sold over 1.5 million copies in the US alone, and had been translated into over two dozen languages. ${ }^{2}$

\footnotetext{
${ }^{2}$ For an excellent overview of Pride and Prejudice and Zombies' publication history and marketing strategies, see Binder 2009 and Nelson 2013. 1.5 million sales of a single novel is increasingly rare in the publishing world. To put things in perspective, sales for all of Sarah Waters's books combined just hit the one million mark in 2014 (O'Keeffe 2014). Though it was a box office failure, viewership of the 2016 film adaptation of Pride and Prejudice and Zombies surpassed this number. Domestic ticket sales for the film are estimated at 11 million (1.3 million viewers, at an average ticket price of \$8.50; Anonymous 2016).
} 
After the unexpected commercial success of Pride and Prejudice and Zombies, a number of other publishers released similar titles. When Lev Grossman of Time magazine asked jokingly, "Has there ever been a work of literature that couldn't be improved by adding zombies?" (Grossman 2009: para. 1), he could not have expected how thoroughly his question would be put to the test over the course of the next few years. Following Pride and Prejudice and Zombies in close succession were Quirk Books' second and third titles in the 'Quirk Classics' series, Sense and Sensibility and Sea Monsters (Winters and Austen 2009) and Android Karenina (Winters and Tolstoy 2010), as well as Jane Slayre (Erwin and Brontë 2010), Little Vampire Women (Messina and Alcott 2010), Wuthering Bites (Gray and Brontë 2010), Alice in Zombieland (Cook and Carroll 2011), and Grave Expectations (Erwin and Dickens 2011) from rival publishing houses, to name but a few of the more popular titles. ${ }^{3}$ Since 2009, a handful of books have formed a mini-canon within the novel-asmashup 'genre'. The novel-as-mashup has well and truly arrived, and with it a new opportunity has emerged to explore postmodern irony's forms, functions, and limits. Does the novel-as-mashup represent the logical extreme to postmodernism's ironic appropriation of history, as author and critic Charlie Jane Anders (un-ironically) suggests in the epigraph above? Or is the novel-as-mashup sincere in its nod to the literary classics of the nineteenth century, and focused on preserving them in cultural memory by bringing them in line with popular culture's current fashions? ${ }^{4}$ Focusing primarily on Pride and Prejudice and Zombies, Sense and Sensibility and Sea Monsters, Jane Slayre, Wuthering Bites, and Grave Expectations, this chapter aims to investigate whether the answers to these questions of irony and

\footnotetext{
${ }^{3}$ In addition to this list, a number of non-literary mashups by the same authors entered the market, including the biofictional works Queen Victoria: Demon Hunter (Moorat 2009), Abraham Lincoln, Vampire Hunter (Grahame-Smith 2010), and Henry VIII: Wolfman (Moorat 2010). Abraham Lincoln, Vampire Hunter was adapted as a major motion picture in 2012. A slew of self-published mashups were also released via online tools like Lulu, and Amazon's CreateSpace and Kindle Direct. Some were more successful than others, and though traditional publicity was certainly an important part of this success, word of mouth on websites like YouTube and GoodReads also helped increase readership for many titles.

${ }^{4}$ Camilla Nelson suggests that, at least in the case of the Pride and Prejudice and Zombies franchise, the novel-as-mashup has tried to fill each of these positions at different moments in time. See Nelson 2013: 339-340.
} 
sincerity do - or should - matter to the study of historical fiction, and neo-Victorianism in particular.

Although scholarly critics like Eckart Voigts-Virchow and David Gunkel remind us of the potential of remix culture and the novel-as-mashup in general (Voigts-Virchow 2012; Gunkel 2012a), they do not specifically explore this potential through close analysis of the novel-as-mashup in a literary context. It is this gap in scholarship that the present article endeavours to fill. I will not attempt to either defend or discount the depth or intellectual merit of the novel-asmashup, or of its readers, as strong cases for both sides of the discussion have been made elsewhere. ${ }^{5}$ Instead, I hope to demonstrate that although these mashups lack a 'serious' relationship with the past, the way they play with the postmodern modes of parody, irony, and nostalgia means that they can still serve as useful tools in the context of neo-Victorianism, specifically with regards to discussions of hermeneutics and ethics. Whatever the original motivation behind the novel-as-mashup, it has generated productive debate within a number of related popular and academic discourses, including remix culture, adaptation studies, and neo-Victorian studies. Each of these discourses is concerned with the nature of our relationship with the past, and with the ironic aesthetic of postmodern art in such a relationship. The novel-as-mashup also demonstrates the problematic nature of these relationships, in that it offers a prime example of how ironic devices can be put to the service of dominant ideologies, calling into question parody and irony's affinities with subversion, and nostalgia's link to unreflective escapism. Before I explain how and why in more detail, it is worth briefly unpacking some of these concepts - many of which are already under discussion.

\section{Irony, Neo-Victorianism, and the Novel-as-Mashup}

While the novel-as-mashup does not draw on the nineteenth century exclusively, ${ }^{6}$ the majority of mashup publications derive their source

\footnotetext{
5 For a sampling of positive reviews and analyses of novel-as-mashup texts, see Schwarzbaum 2009; Anders 2009; Itzkoff 2009; Bowman 2009; Jen 2010; and Mattin 2012. For a sampling of negative reviews, see Schuessler 2009; Anderson 2009; Kaufmann 2009; Halford 2009; [Anonymous] 2010; Stevens 2015; Swinehart 2015, and De Groot 2016.

${ }^{6}$ Take Cook Coleridge's 2011 The Meowmorphosis, also from Quirk Books, which combines Franz Kafka's 1915 classic novella The Metamorphosis with the internet
} 
material from the Regency and Victorian eras of England's literary history. As many of the texts appropriated by the novel-as-mashup originated in nineteenth-century Britain, the key paradigm with which the novel-as-mashup potentially intersects is the academic field of neo-Victorian studies, ${ }^{7}$ and the "postmodern rewritings of Victorian culture" with which it concerns itself (Sadoff and Kucich 2000: xi). Over the past two decades this relatively new field has attempted to redefine its focus and scope, in order to better encompass all that can be considered 'neo-Victorian'. In neo-Victorian studies, irony, parody, and nostalgia have each served as important conceptual frameworks for illustrating the way the past is used (and abused) in the present.

Does the novel-as-mashup fall into this 'neo-Victorian' category? Arguably not if one takes Ann Heilmann and Mark Llewellyn's seminal definition of the neo-Victorian project. They describe neo-Victorianism as inherently metatextual, comprised of texts that "must in some respect be self-consciously engaged with the act of (re)interpretation, (re)discovery, and (re)vision concerning the Victorians" (Heilmann and Llewellyn 2010: 4, original emphasis). A certain amount of ironic self-awareness is certainly present in the construction of the novel-as-mashup. Jason Rekulak, who provided the initial idea for Pride and Prejudice and Zombies, has cited the internet's myriad publishing options as his inspiration, where artists can allegedly "get away with" flouting copyright concerns in a way that he, as a traditional book publisher, normally cannot (Rekulak 2009: para. 2). As this sentiment indicates, the relationship between the novel-as-mashup and the texts it appropriates may not be as intimate or traditionally literary as Heilmann and Llewellyn's definition broadly implies. Though the novel-as-mashup is engaged in metatextual reference, its appropriation of classic literature, verging on plagiarism, is arguably less concerned with the Victorians than it is with instant recognisability and, following the commercial success of

phenomenon of lolcats: humorous phrases and anthropomorphic sentiments transposed over endearing images of cats.

${ }^{7}$ Nadine Boehm-Schnitker and Susanne Gruss specifically argue for the novel-asmashup's consideration as part of the neo-Victorian phenomenon in their introduction to the 2014 edited collection Neo-Victorian Literature and Culture (Boehm-Schnitker and Gruss 2014b: 3). 
Pride and Prejudice and Zombies, with profit generation. ${ }^{8}$ Traditional publishing's extensive copyright laws are no doubt partly responsible for the selection of these particular period texts, and mashup artists' preference for texts already in the public domain is understandable in this restrictive context. ${ }^{9}$ The texts appropriated in the novel-as-mashup also tend to be those kept alive by a seemingly endless series of adaptations, whether for stage, television (especially by the BBC), or cinema. ${ }^{10}$ Metatextuality, then, is not the defining impetus of the novel-as-mashup. Rather than mixing Victorian works with contemporary fads and fashions by metatextual design, the novel-asmashup may simply be neo-Victorian through monetary calculation and practical coincidence.

Like Heilmann and Llewellyn, Kate Mitchell seeks a deeper, more self-aware type of neo-Victorianism in her 2010 study, History and Cultural Memory in Neo-Victorian Fiction. She describes the dichotomy in neo-Victorian fiction as follows:

The issue turns upon the question of whether history is equated, in fiction, with superficial detail; an accumulation of references to clothing, furniture, décor and the like, that produces the past in terms of its objects, as a series of clichés, without engaging its

\footnotetext{
${ }^{8}$ Nelson argues that such mashups are primarily twenty-first century texts, and are less interested in dialogue with the past than they are with ventriloquising it. See Nelson 2013: 352-353.

${ }^{9}$ To date the only novel-as-mashup to be published (through official channels) in conflict with US copyright law is The Late Gatsby (Klipspringer and Fitzgerald 2012). This book is only for sale outside the US, where different copyright laws and lengths apply, and it is currently only available as an ebook.

10 In some instances the novel-as-mashup seems to be referencing subsequent adaptations more than the novel it appropriates. Consider Pride and Prejudice and Zombies, where instead of noting that there is "something of dignity in his countenance that would not give one an unfavourable idea of his heart" (Austen 2008: 162), Elizabeth Bennet notes 'something of dignity in the way his trousers cling to those most English parts of him' (Grahame-Smith and Austen 2009: 206). This sexualisation of Darcy seems related less to Austen's characterisation and more directly to the 1995 BBC adaptation of Pride and Prejudice (or the 2008 miniseries Lost in Austen), in which Mr Darcy emerges from the water in a near-transparent shirt. This scene (and the swooning it provoked) has become so well-known it was recently commemorated with a 2013 re-enactment in Hyde Park (see Lyall 2013). Nelson suggests that Pride and Prejudice and Zombies may be even more indebted to these adaptations than it is to Austen's novel (Nelson 2013: 342).
} 
complexities as a unique historical moment that is now produced in a particular relationship to the present. [...] Can these novels recreate the past in a meaningful way or are they playing nineteenthcentury dress-ups? (Mitchell 2010: 3)

We can again see an element of humour in this metaphor, in the image of a twenty-first century text gleefully 'trying on' the past in childish play. Here the novel-as-mashup clearly falls into Mitchell's second, implicitly meaningless category: it is unabashedly engaged in nineteenth-century dress-ups, delighting in its objects and clichés. In the many illustrations in Pride and Prejudice and Zombies, for example, the Bennet sisters are clad in the Regency dresses so often depicted in BBC dramatisations of Austen's novel, but for fighting they wear their "sparring gowns" (Grahame-Smith and Austen 2009: 130). These gowns remain largely faithful to the BBC aesthetic, but also incorporate steampunk elements like leather corsets and gun belts. ${ }^{11}$ The material, historical reality behind certain Regency items of clothing is glossed over by the popularity of their revised forms in contemporary culture and fashion. In the novel-as-mashup, the parasol serves a similar function to the zombie as an object and cliché of popular fiction. It is the instant recognisability of these Regency items of clothing, made popular in contemporary culture by steampunk, that makes them so attractive to novel-as-mashup readers, authors, and publishers.

The novel-as-mashup seems designed primarily to entertain, not to "recreate the past in a meaningful way" in the sense Mitchell describes (Mitchell 2010: 3). The turn of neo-Victorian studies to, as Marie-Luise Kohlke puts it, "lighter", less serious forms of writing

\footnotetext{
${ }^{11}$ As a subgenre (and subculture) that is "often specifically neo-Victorian" (Domsch 2012: 109), steampunk is often considered as little more than an aesthetic, perhaps for the very reason that "the only definitive trait shared by most steampunks seems to be an aesthetic one, namely a common interest in the visual interface between retroVictorian style and contemporary technology" (Ferguson 2011: 67). Though this diversity makes it difficult to say definitively that the novel-as-mashup should not be categorised as steampunk, the novel-as-mashup is neither as politically motivated as much steampunk fiction (see Rose 2009), nor as involved with contemporary technology as Ferguson describes. Instead, the steampunk aesthetic (as appropriated by mainstream culture) simply becomes another easily recognisable cornerstone on which the novel-as-mashup can ground itself.
} 
marks another area of debate in neo-Victorianism, not only in the sense of whether or not these texts are funny (a regular bone of contention in the case of the novel-as-mashup), but also whether texts that do not "promote serious historical insight or revision" can still serve as meaningful additions to the neo-Victorian field (Kohlke 2014: 33, 34). Though her analysis of comedic texts maintains a certain level of literariness, Kohlke argues that it is not only "serious" representations of the Victorians that merit academic study (Kohlke 2014: 34). As she demonstrates, metatextuality can extend into the comic mode, expressing a humorous or tongue-in-cheek awareness that still fits into existing neo-Victorian theory on representations of gender, race, and class (Kohlke 2014: 34). Though texts that do not use the past seriously can nonetheless be ironically self-aware, it is still not entirely clear what this means for more superficially parodical genres like the novel-as-mashup. Where the type of comedic awareness Kohlke discusses may productively deal with and enact cultural critique or social change, the type found in the novel-asmashup might not.

In the context of this discussion of humour, self-awareness, and the neo-Victorian, it is worth briefly highlighting the way postmodern irony tends to parody contemporary culture's nostalgia for the past, as noted in many studies of neo-Victorian fiction. ${ }^{12}$ In a conversation with Mario Valdés, published in 2000, Linda Hutcheon visits the subject of postmodern nostalgia, specifically as it relates to irony. ${ }^{13}$ For Hutcheon, postmodern irony has an inherently nostalgic aspect, though this aspect is ultimately overwritten. The nostalgic move of postmodern irony is "both an ironizing of nostalgia itself, of the very urge to look backward for authenticity, and, at the same moment, a sometimes shameless invoking of the visceral power that

12 See, for example, Gutleben 2001, Carroll 2010, Sulmicki 2011, and Rousselot 2014, who in turn draw on Hutcheon and Jameson's explorations of nostalgia and irony (see Hutcheon 1995a and Jameson 1988). In arguing that all neo-historical fiction rejects (or even exploits) outright nostalgia, Elodie Rousselot asserts that the "paradoxical fascination with/subversion of history becomes a powerful means of challenging, rather than confirming, the exoticist drives of the present" (Rousselot 2014:12).

${ }^{13}$ Here irony is described both in the literary sense - "either in its rhetorical or New Critical meanings or in its more extended senses of situational irony or, with an historical dimension, of 'romantic' irony" - and in the "ironic double vision" of the postmodern (Hutcheon and Valdés 2000: 30, 34). 
attends the fulfilment of that urge" (Hutcheon and Valdés 2000: 34). Before being ironically dismissed, the nostalgia inherent in contemporary culture must first be evoked in all its conservative glory. The postmodern parts of this nostalgic contemporary culture "are aware of the risks and lures of nostalgia, and seek to expose those through irony" (Hutcheon and Valdés 2000: 34). For Hutcheon, these risks and lures consist largely of confirming "modernist assertions of originality, authenticity, and the burden of the past" (Hutcheon and Valdés 2000: 34).

The novel-as-mashup does not seem to belong directly within either of these categories - neither with those texts that are selfconsciously fascinated with nostalgia nor those ironically debunking its attractions. Although it looks to the past for its inspiration, the novel-as-mashup is not nostalgic; it does not sentimentalise or valorise the past or its texts in any intentional way. Nor does it truly set itself up as superior to the past, though it does use irony (in both text and paratext) to disparage both the object of nostalgia it appropriates and its own appropriation of that object. Consider the following excerpt from the back cover of Pride and Prejudice and Zombies, and the qualities it attributes to the two authors it mentions:

Jane Austen is the author of Sense and Sensibility, Persuasion, Mansfield Park, and other masterpieces of English literature. Seth Grahame-Smith once took a class in English Literature. He lives in Los Angeles. (Grahame-Smith and Austen 2009: back cover)

This description belittles Grahame-Smith in an ironic way by suggesting that he is lazy and uneducated. Although Grahame-Smith's degree is in film rather than literature, his extensive writing work in various media, as well as his experience in film and television production, contradicts this suggestion. Likewise, the ironic inclusion of Austen in the author blurb both suggests that she would approve of the appropriation (which is a separate question entirely), and that she and Grahame-Smith are on equal footing as authors of the novel-asmashup. Pride and Prejudice and Zombies unabashedly capitalises on nostalgia for the world and work of Jane Austen, belittling Pride and Prejudice's legacy with the promise to transform "a masterpiece of world literature into something you'd actually want to read" 
(Grahame-Smith and Austen 2009: back cover). At the same time, Grahame-Smith denies that Pride and Prejudice and Zombies is a parody, stating "it wasn't my intention to make fun of the original. Pride and Prejudice is a brilliantly written book by a brilliant author, and all I wanted to do was give its themes and characters an absurd canvas to play out upon" (Harvison 2009: para. 12). Grahame-Smith takes the novel's commercial success as a sign that readers understand its humour, and "see it for what it is - a silly, entertaining way to revisit a timeless classic" (Harvison 2009: para. 16).

Given such contrasting messages, it can be difficult to discern whether the novel-as-mashup (and other fantastical - or simply inane - historical fictions) are 'playing dress-ups' naively and nostalgically, or out of ironic self-awareness. Provided these are the only two options, the political and ethical implications of such an un-ironic turn towards nostalgia are equally unclear. In textual art, irony relies on its interpreter's recognition that what is being shown or said is at odds with the meaning or intention behind that image or statement. Irony also relies on the reader accepting (at least on some level) that the meaning or intention being ironised is indeed worthy of such treatment. In a novel-as-mashup like Pride and Prejudice and Zombies, the reader is expected to note the incongruent modification of a literary classic like Pride and Prejudice with a popular horror icon like zombies, as well as the novel's ironic presentation as a selfdeclared "expanded edition of the beloved Jane Austen novel" (Grahame-Smith and Austen 2009: back cover). In a feat of situational irony, the publicity team for Pride and Prejudice and Zombies effectively asks the reader to recognise that they are being manipulated, and then to enjoy the process. Though Pride and Prejudice and Zombies is certainly an ironic text, whether it is ironic in the same way many definitions of neo-Victorianism and postmodern fiction describe is another matter.

If anything, the novel-as-mashup seems to represent a case of doubled irony, aligned with its categorisation as camp, rather than an ironic nostalgia for the past that is specifically postmodern. Unlike kitsch, which tends towards un-ironic nostalgia, camp takes the opposite approach to "layer irony upon irony" (Linstead 2002: 161). Where irony hints at an alternate (if indirect) meaning, the double irony of camp refutes meaning altogether, suggesting "that however reflexive we are we will only know reflexivity" (Travers 1993: 128). 
When understood as a reflexive relationship rather than a reflective one, the play between irony and nostalgia in the novel-as-mashup potentially takes on a different meaning. This requires a both/and approach to interpretation. When a text like Grave Expectations uses lycanthropy as a metaphor for male adolescence, and represents the misandrists Miss Havisham and Estella as monster slayers, it can ironically literalise the role of these characters in Great Expectations, who hunt men because they are physical monsters. It can also ironically parody the existence of the misandrist altogether, in the context of anti-feminist sentiment. Women who think men are metaphorical monsters are, by association, as silly as these mashup characters. The novel-as-mashup is often both nostalgically faithful to the texts it appropriates, hence conservative, and ironically critical of its appropriated text's ideologies, and therefore transformative. Reflexive (rather than reflective) irony potentially allows for radically different readings and interpretations.

Rather than attempting to ironise a literary classic "in ways that enrich the narrative without derailing it", as Samantha Carroll advocates in her analysis of ironic nostalgia, the novel-as-mashup confronts us with the possibility that enrichment and derailment may not be the only two options available (Carroll 2010: 183). Moreover, it suggests that these two options need not be mutually exclusive. Rather than critiquing directly, as ironic parody does, the novel-as-mashup mobilises both the nostalgia contemporary culture evinces for the textual past and the ironic responses to such nostalgia, multiplying the number of possible readings it allows, and thereby increasing its chances at wider dissemination and acceptance as well. As a result of this broad focus, the critique enacted by the novel-as-mashup is generally not very deep or particularly political - at least, not in the way Hutcheon (or many a neo-Victorianist) describes it.

In the introduction to their 2014 collection Neo-Victorian Literature and Culture: Immersions and Revisitations, Nadine Boehm-Schnitker and Susanne Gruss argue for a new extension of the definition of neo-Victorianism that moves beyond the postmodern:

Even though postmodernity remains a helpful reference point for academia, writers and artists, neoVictorianism has moved beyond postmodern concerns such as intertextuality, self-reflexivity or metafiction. 
Despite postmodernity's ongoing relevance, neoVictorianism calls for newly calibrated tools of analysis which enable us to approach it as a symptom of a contemporary literature and culture which more strongly integrates questions of ethics, reconsiders the author, allows the referent to become visible again behind the veil of material signifiers, and plays at and with practices of immersion. (Boehm-Schnitker and Gruss 2014b: 2)

The novel-as-mashup certainly presents us with some of these tools. Furthermore, it does so in a way that both reintroduces and sidesteps many of the problems introduced by postmodern irony. Although its irony is not particularly progressive in Gutleben's description, the way it already inherently addresses the issues outlined by Boehm-Schnitker and Gruss suggests that the form nonetheless has interesting potential within the field of neo-Victorianism. The novel-as-mashup asks its readers to suspend their disbelief and embrace ironic distance in a way that is both playful and ultimately paradoxical. As I hope to demonstrate, though it does not engage with these discourses in the depth scholars may prefer, by 'dressing up' in both Victorian and postmodern guises, the novel-as-mashup raises questions of ethics, points to the continued role of the author in twenty-first-century poststructuralism, and attempts to re-ground material signifiers in their various referents. In Boehm-Schnitker and Gruss's vision, neoVictorian texts help us to move forward, as well as letting us look back. The novel-as-mashup provides us with an ideal opportunity to address the limits and limitations of postmodernism's ironic nostalgia, and to showcase the potentially productive uses that still remain for both irony and nostalgia, in the realm of hermeneutics and ethics alike.

\section{Hermeneutics: Immersion, Author and Referent}

The first problem with postmodern irony, as highlighted by the novelas-mashup, has to do with hermeneutics and the idea of ironic reading as 'serious business'. In much of postmodernism, specifically those texts highlighted by literary scholars, ironic parody tends to be quite politically serious. What humour is present in postmodern historical fiction often lies rather bitterly in the need for irony at all, i.e. that the 
nostalgic view of the past it presents and rejects is not already recognised as unattainable (and ultimately undesirable). Consider Sarah Waters's retroactive attempts to de-marginalise lesbianism, by re-imagining the Victorian world in which lesbians were originally "vilified or eclipsed by the historical record" (Carroll 2010: 195). Although this restoration is an ironic one, as Carroll points out it is also a very serious act of "recognitive justice", serving to "destabilise deep-structure inequalities" (Carroll 2010: 195). While the object of irony is sometimes made ridiculous in ironic parody, the motivation for the irony itself often is not.

With the majority of its real-world 'others' replaced by fantastical monsters, the novel-as-mashup instead verges on a parody of such serious (if ironic) revisionism, using lowbrow camp to invert both politically correct and overtly political uses of irony. Consider Alice in Zombieland, in which the cartoon violence of the novel-asmashup actually lessens the irony and humour present in Alice in Wonderland, distancing readers from the inherent queerness (for lack of a more 'curious' word) of the text and its characters. When the Cheshire Cat remarks "we're all dead here. I'm dead. You're dead" (Cook and Carroll 2011, 83), the March Hare is instead the Dead Hare, and the card soldiers become the 'dead soldiers' in Alice in Zombieland, some of the absurdity and darkness of Carroll's original is in fact lost in the conversion, overwritten again and again by the same joke about zombies.

It is not just repetition that subverts irony. As both Gutleben and Hutcheon point out, all irony weakens over time. The politically relevant ironies of one time and place are not those of another, rendering once-progressive writings potentially impotent. This process is perhaps all the better illustrated by the novel-as-mashup, which consciously aims to "update" and fill perceived gaps in classic texts (Collis 2009: para. 1). ${ }^{14}$ In addition to slippage of meaning caused by the passage of time, the appearance of political progressiveness is also

\footnotetext{
${ }^{14}$ In this interview about Pride and Prejudice and Zombies, Seth Grahame-Smith also states: "when you take a look at the original book, it's almost as if, subconsciously, Jane Austen is laying out the perfect groundwork for an ultraviolent bone-crushing zombie massacre to take place. For instance, there's a regiment of soldiers camped out near the Bennett household. In the book, they're just there for characters to flirt with. But it's not that big a leap to say, Okay, they're there because the countryside has been overrun with what they call the 'unmentionable menace"' (Collis 2009: para. 2).
} 
affected by the respective readership and culture judging a text. Textual progressiveness does not automatically equal real-world progress. This plurality of irony makes situating the novel-as-mashup especially difficult, particularly given the double discourse such mashups incorporate. If nothing else, the novel-as-mashup's extreme re-contextualisation of English literature's most popular canonical novels allows us a modicum of distance from texts with which we might otherwise be too familiar.

Much of the irony of the novel-as-mashup is situational as well as textual, meaning that whether it is recognised depends greatly on an individual reader's relationship to the appropriated text. For Hutcheon, irony can also be created by the reader, disrupting "the neat theories where the interpreter's task is simply one of decoding or reconstructing some 'real' meaning (usually named as the 'ironic' one)" (Hutcheon 1995a: 11). The blurred distinction between textual irony and reader-manufactured irony can again be seen in the tonal shift of the publicity for Pride and Prejudice and Zombies, which without any alteration to the text itself - shifted from an "anti-fan" stance to a much more reverential one following the novel's positive reading by Austen fans (see Nelson 2013: 339, 341). Where Quirk Books saw irony in its irreverence towards Austen, readers (ironically) failed to see irreverence at all.

In addition to blocking our direct access to a unified reading, the novel-as-mashup at once allows and denies us direct access to the author: that singularly humanist figure who, contrary to Barthesian assertions, refuses to die. Jane Austen remains as famous as ever following the release of Pride and Prejudice and Zombies, and her 'co-author' Seth Grahame-Smith, though not elevated to the same level, has received wide recognition for this and subsequent mashup works. Though the novel-as-mashup does not 'kill' the author in the sense of granting anonymity or irrelevance, it does call into greater question the centrality of authorial intention and creative genius. Pride and Prejudice may well be inherently original in one sense, but it is also a cultural object that we are fully free to adapt in the creation of our own meaning.

It is not entirely clear why the particular configuration of "combinations, contradictions, and resonances" (Gunkel 2012b: 18) in the novel-as-mashup are acceptable to many, and unacceptable to many others. The line between acceptable and unacceptable forms of 
irony can be a fine one, and is often purely a matter of context. Although irony is a primary (and thus readily recognisable) form of humour in postmodern culture (see Hutcheon 2000; Gutleben 2001), even when successful, it is always a question of ethics, politics, and aesthetics. This is doubly true when it involves marginalised groups or individuals, religion, or historical trauma (see Lockyer and Pickering 2005). One need only look at the recent Charlie Hebdo shootings and controversy to confirm this assertion. Irony can be used to point to both serious and trivial issues. Whether it is productive is always a question of perspective, and it is not always an intellectual exercise. Both the novel-as-mashup and other, less controversial mashup texts ${ }^{15}$ are technically doing the same thing: inserting fantastical characters and images into historical contexts. The creation of ironic distance (and subsequent suspension of disbelief) allows the one to be deemed acceptable while the other is potentially upsetting.

As Simon Critchley suggests in his 2002 book On Humour, ironic recognition and humour are actually "a form of cultural insiderknowledge, and might, indeed, be said to function like a linguistic defence mechanism" (Critchley 2002: 67). Those who do not speak the language are excluded from the joke, to the point where "having a common sense of humour is like sharing a secret code" (Critchley 2002: 68). This system of exclusion is what Hutcheon has referred to as "irony's edge", which "manages to provoke emotional responses in those who 'get' it and those who don't, as well as in its targets and in what some people call its "victims"” (Hutcheon 1995a: 2). The victims Hutcheon describes are those people who miss a text's irony entirely, and/or those who are the object of the irony. These are also the people excluded and potentially hurt or offended by said ironic displays.

Many examples of a rupture in ironic distance can be found in the novel-as-mashup's various portrayals of the class divide. Although the novel-as-mashup generally retains the same class distinctions as depicted in the appropriated texts, certain aspects of the class hierarchy are often re-emphasised or made literal in the twenty-firstcentury adaptations. In Jane Slayre, the Reed family is transformed from figurative blood-suckers into literal ones: they and the families

${ }^{15}$ Consider works like Kim Newman's 1992 novel Anno Dracula, Alan Moore and Kevin O'Neill's comic book series The League of Extraordinary Gentlemen (19992015), or the Showtime/Sky series Penny Dreadful (2014-present), all of which directly appropriate multiple characters, themes, and plotlines from classic literature. 
with which they associate are all vampires, the traditional monsters of the upper class. ${ }^{16}$ In contrast, the servant Abbot is a zombie, and the typhus epidemic at Lowood becomes an unexpected zombie plague, literalising the zombie as the "monster of the people" (Grossman 2009). In light of many Marxist readings of Austen's work, specifically Pride and Prejudice, the zombies in Pride and Prejudice and Zombies could also be read as an ironic manifestation of the almost-invisible working class in the original novel. ${ }^{17}$ These are the kinds of alterations most frequently applauded by critics.

Some mashups choose to make more dramatic comments on the division between the landed gentry and the working classes, though similar sentiments may not appear at all in the original novel. These additions are instead derived from twenty-first-century perceptions of the period, and however grounded in a historical reality they may be, are more often perceived as direct attacks on the appropriated texts than the literalisations described above. An entire passage reflecting the uncaring attitude of characters in Wuthering Heights towards the servants is added to Wuthering Bites. Cathy Linton is out visiting her pony in the stables when she stumbles across a vampire attacking one of the household staff. Cathy's first instinct is to shout: 'Get off her this moment. This girl is our maid and she has duties to attend to' (Gray and Brontë 2010: 399). When the vampire refuses to retreat, she is forced to kill him before he kills the maid, but only because 'if he killed Sally, I knew it would take days to replace her, as her mother was so difficult to convince sending her after the first four of her daughters were murdered in service here' (Gray and Brontë 2010: 400).

\footnotetext{
${ }^{16}$ Apart from Bram Stoker's infamous Dracula (1897), there are a myriad of vampire narratives from the late nineteenth century that typify the upper class as vampiric, for example Arabella Kenealy's 'Some Experiences of Lord Syfret' (1896). In this short story, the Lady Deverish sucks the life force from her household servants by touch, through her own sickly and needy energy. See also Mary Elizabeth Braddon's 'Good Lady Ducayne' (1896), in which the blood of Bella, the young and vivacious companion to the titular protagonist, is slowly siphoned away without her knowledge, presumably given in transfusion to her elderly and ridiculously wealthy employer.

17 This characterisation of zombies as everyday 'working stiffs' is also not as harmlessly humorous as it might seem. Recent academic studies show the zombie is frequently used as a de-humanised metaphor for groups of people considered distasteful to the public, such as immigrants, enemy combatants, etc. (see McNally 2012 and Gordillo 2014).
} 
Sense and Sensibility and Sea Monsters, to take another example, delivers the following excerpt in the middle of the novel. It takes place in Sub-Marine Station Beta (replacing the London of the appropriated text):

It only contributed to the awkwardness when a loud bang was heard against the glass back wall of the docking; turning their heads, they saw that a servant, who had been changing the water filtration tank and come detached from the breathing hose of his special Ex-Domic Float-Suit, was clamouring for their attention. The operations of the Station's various lifesustaining apparatuses were meant to be entirely invisible to the inhabitants, and the man's noisy exhibition was a rather embarrassing violation of decorum; Elinor and her guests studiously ignored him, and his increasingly insistent thrashing became the background to the ensuing uncomfortable exchange. (Winters and Austen 2009: 337)

The choice to invent this scene, and such a callous response from the novel's main characters, seems to reflect judgement of the period in general by the twenty-first-century author, rather than an addition based on explicit evidence in the appropriated novel. Its addition also undermines Elinor's primary role in the novel as a sensible, sensitive, and sympathetic force, without offering any real substitute or counterbalance. Here the text's generally ironic alterations become harsh and judgemental. They not only question the absence of the working class in Sense and Sensibility, but imagine its abuse at the hands of characters whose wealth or station engenders a needless obsession with decorum and concern for their own comfort. To readers who do not read working-class struggles into Sense and Sensibility, or who feel particularly close to its characters, such representations could be alienating. In these cases, the question of whose feelings and ideologies are being attacked becomes particularly important. Typically the novel-as-mashup reinforces the perspective of the cultural majority, and not of those traditionally classed as others - though as I will demonstrate in the following section, there are exceptions to this rule. 


\section{Ethics: Ironic Distance and Otherness}

In addition to the issue of ironic distance and hermeneutics, the neoVictorian novel-as-mashup foregrounds the tendency of postmodernist fiction to ironically reproduce problematic ideologies. When attempting to reproduce or adapt the past in fiction, questions of imperialism, racism, and sexism inevitably arise - particularly when we are speaking about the Victorian past. Whether or not a text approaches this past ironically, we can never be sure such irony will be interpreted as intended. Irony (and humorous irony in particular) has an inherently exclusionary function - one that often reproduces oppressive power structures. This means that Irony already tends towards elitism, whether that elitism is considered to be subversive, oppressive, or simply undirected. Colebrook neatly summarises this problem as follows:

On the one hand, irony challenges any ready-made consensus or community, allowing the social whole and everyday language to be questioned. On the other hand, the position of this questioning and ironic viewpoint is necessarily hierarchical, claiming a point of view beyond the social whole and above ordinary speech and assumptions. (Colebrook 2004: 153)

In other words, while irony may question the status quo, it relies on the very framework it criticises to do so. How can we know something is ironic if we do not also recognise what is expected? In a continual, familiar struggle, postmodern art has often inadvertently supported or recreated the very systems it attempts to undermine, generally as a result of its ironic structure. As Colebrook points out:

Postmodern literature has been dominated by texts that express a masculinist, imperialist, racist or elitist discourse in order to present the violence of that discourse. [...] And even if one were to decide that such texts were, or ought to be, ironic, this would still allow the violent content to be displayed, enjoyed and popularised. (Colebrook 2004: 157) 
This issue of ironic reproduction speaks to current concerns within neo-Victorianism as well. Consider Australian Prime Minister John Howard's accusation that postmodern versions of Australian history represent "little more than a litany of sexism, racism and class warfare" (Howard qtd. in Carroll 2010: 191). Analogously, in her 2015 monograph Neo-Victorian Freakery, Helen Davies questions whether "neo-Victorianism distorts freak show performers beyond all recognition, compounding nineteenth-century abuses of vulnerable people" (Davies 2015: 3).

Though it frequently abuses canonical, 'establishment' texts, the novel-as-mashup is also guilty of the exoticising depiction (and exploitation) of potentially vulnerable people. Consider Sense and Sensibility and Sea Monsters, where Sir John Middleton is depicted as an imperialist adventurer, who has kidnapped his wife Lady Middleton from Africa. Lady Middleton's escape attempts are a running joke in the novel, and although they are intended for comedic effect, they reference a very real Victorian power dynamic, both between husband and wife, and between master and slave. Despite the Barthesian 'death of the author' and the New Critical step away from authorial intent, readings of Sense and Sensibility and Sea are complicated by the fact that Winters is himself a middle-class man of European descent, profiting from a story in which a middle class European man exploits a black African woman. Rather than challenging the exploitation of various groups and individuals, many novel-as-mashup texts risk perpetuating unwanted sentiments, stereotypes and ideologies, particularly if read un-ironically.

The shift towards political correctness and the post-racial does not represent an adequate solution to irony's potential reproduction of the very hierarchies and ideologies it seeks to undermine. This still tends to result, practically speaking, in a scenario where Western values, masculinity, and whiteness function as 'the norm' against which political correctness is measured. The novel-as-mashup, with its commercially palatable narrative strategies, is no exception to this. Despite the novel-as-mashup's superficial subversion of gender roles through its use of female action heroes, it is worth noting that no effort has yet been made to insert any type of non-heterosexual relationship into a literary classic, despite the free reign given to the authors to alter similar aspects of the classical narratives. Occasionally homosexual subtext present in the source material is even diffused or 
negatively reinforced, as in Jane Slayre, where Jane is forced to kill her dear friend Helen Burns, with whom she shared an ambiguously intimate relationship. Jane's slaying of Helen immediately follows an unmodified passage from Jane Eyre, in which Helen and Jane are sleeping in the same bed. This indirectly reinforces the idea that socially transgressive kinds of intimacy will be punished.

The fact that the novel-as-mashup combines two popular genres, romance and horror, that are still traditionally dominated by mainstream culture, certainly contributes to its resistance of subversive politics in favour of cliché. Through its use of fantastical monsters, it does address the problem of political whitewashing in a unique way, however. The novel-as-mashup's use of monsters is not unproblematic, as specific monsters are still gendered and racialised in different ways. Fantastical monsters are also traditionally associated with ethnic minorities in Gothic and horror fiction (see especially Halberstam 1995). The creators and audiences of novel-as-mashup texts (many with degrees in literature and history themselves) are often aware of the academic and psychoanalytical discussions surrounding the figure of the monster, using them to literalise related physical, sexual, or emotional attributes. In Jane Slayre, for example, the madness of Bertha Rochester is not only connected to her status as both female and foreign, but also to the fact that she is a werewolf (Erwin and Brontë 2010: 614). Though the werewolf is a fantastical monster, it also has direct cultural connotations of animal emotion and exotic ethnicity, which still tie back to her status in the appropriated novel. The novel-as-mashup clearly also maps monsters onto historical categories of otherness for comedic effect, although the ethnic reference or humour used often attempts inclusivity. In Wuthering Bites, for example, the outcast gypsies with whom Heathcliff identifies are transformed into a heroic clan of vampire slayers. As Mr Lockwood notes, "it is their skill and courage that keep the beasties from devouring all of us and taking over our fair country" (Gray and Brontë 2010: 15).

Because of the way monsters change the context and stakes of the novel's action, portrayals of petty, weak, or mad women also tend to be softened in the novel-as-mashup. Traits that may previously have been associated most strongly with femininity are instead given a fantastical motive. Some women are transformed into fantastical monsters rather than metaphorical ones, as is the case 
with Jane Slayre's Mrs Reed, Abbott, and Bertha Rochester, for example. Though not absolved of their personal or emotional faults, they are at least partially forgiven by the protagonist because it is in "their very nature" (Erwin and Brontë 2010: 76) as monsters (and not humans) to behave in such a way. Any humour drawn from their flaws becomes focused on their monstrous nature, and not their gendered one. Likewise, Alice in Zombieland's Red Queen is demanding and overbearing because she is attempting to hold back a zombie apocalypse, and not because she is a woman in power. Miss Havisham and Estella of Grave Expectations are a danger to Pip because they are hunters and he is a werewolf, not because they seek revenge against all men. These fantastical monsters represent otherness, but not a particular 'other'. Drawing marginalised characters from classic literature into mainstream monster culture serves to legitimise them as symbols without emphasising their otherness. They serve as a buffer between the audience and any particular racialised, gendered, or class implications. If the reader misses the irony, all that remains is a comedically misplaced monster in a Jane Austen novel, and not a specifically racialised, classed, or gendered body. In this way, the novel-as-mashup's campy, fantastical monsters can potentially raise questions of ethics without directly reproducing ironic inequalities.

Despite their limitations as symbols, then, the monsters in the novel-as-mashup add a layer of mediation to these representations of otherness. Like the novel-as-mashup itself, they exist to induce reflexive laughter, rather than to inspire horror or ironic reflectivity at the otherness of non-conforming bodies or cultures. These monsters defer or deny meaning through camp rather than deflecting (or reflecting) meaning through irony. As fantastical monsters, which are further removed from real-world stigma than metaphorical monsters by virtue of their implausibility, they can potentially single out cases of imperialism, colonialism, or patriarchy without at the same time singling out a particular minority victim.

\section{Conclusion: Nonsensical Forces}

To briefly return once more to Boehm-Schnitker and Gruss's suggestions about the future of neo-Victorianism, it seems well worth 
considering whether the neo-Victorian fiction of the twenty-first century can (or should) be considered wholeheartedly postmodern. ${ }^{18}$ Regardless of how we categorise the novel-as-mashup, its creation of parallel discourses and contradictory affiliations is clearly of interest to neo-Victorianism, not least in terms of its parody of both Victorian and neo-Victorian fiction. By directly combining texts from the nineteenth century with postmodern figures and forms, the novel-asmashup is able to oscillate between the various readings and implications of both Victorian and twenty-first-century discourses. It carries the accumulated baggage placed on its appropriated nineteenth-century monsters and texts by more than a century of critical examination, but it also creates some space for a reinterpretation of this baggage - reviving the monster, as it were.

The novel-as-mashup's recycling of historical texts in a postmodern context offers us a way to briefly revive old monsters and monstrous discourses, allowing us to continually question whether they serve us better dead, or perpetually undead. For all its inherently conservative motives and methods, the novel-as-mashup's deferral of meaning can be a valuable tool, highlighting the fault lines in neoVictorian fiction's use of postmodern irony. For Hutcheon, it is precisely such deferral, present to a certain degree in all historiographic metafiction, that finally creates space for "a consideration of the different and the heterogeneous, the hybrid and the provisional. This is not a rejection of the former values in favor of the latter; it is a rethinking of each in the light of the others" (Hutcheon 1988, 42). The fragmentation and formlessness inherent in historiographic metafiction should ultimately allow for the formation of new and unexpected connections. This, I would argue, is something the novel-as-mashup achieves admirably.

Colebrook, drawing on Derrida's poststructuralist theory, argues that "all speech is potentially ironic, both because a concept has a sense we neither author nor control and because there are

\footnotetext{
${ }^{18}$ Though I do not think it necessary to come down strongly for or against the death of postmodernism, if we declare something dead often enough, eventually it becomes a self-fulfilling prophecy - and a prospect worth considering. Linda Hutcheon has herself voiced suspicions about postmodernism's lifespan in the epilogue to the most recent edition of The Politics of Postmodernism, stating: "Let's just say it: it's over" (Hutcheon 1995b: 166-167). See also Eshelman 2008; Kirby 2009; Bourriaud 2009; Moraru 2013; Nealon 2012; Vermeulen and van den Akker 2010.
} 
nonsensical forces at work in the articulation of concepts" (Colebrook 2004,169 , original italics). Colebrook sees these nonsensical forces as the ways in which unintended meaning can be written or read into all communication. In cultural criticism today, the difficulties inherent in this assumption are under continual scrutiny. Colebrook's tentative solution to such difficulties is this:

We would need to acknowledge the problem of sense or meaning beyond manifest intent, as in classical irony, but we would also need to read for the inhuman, machinic or errant forces that preclude such a sense from governing the text (Colebrook 2004, 169).

In other words, we must continue to search for ironic or alternate readings of texts, while also remaining open to the possibility of a third, as-yet-unknown way, where meaning runs rampant. This is the ground on which the concepts of opacity and sincerity find a strange union with irony, and on which the novel-as-mashup finds its home. It reminds us that, when we are asked to choose between a reading favours either progressive irony or conservative nostalgia, there is always a third option: zombies (inhuman, nonsensical deferral). Questions of irony and nostalgia do certainly matter in neo-Victorian fiction, and though the novel-as-mashup fails to take such questions seriously, it usefully reminds us of the limitations and potential pitfalls inherent in framing such a discussion.

\section{Bibliography}

Anders, Charlie Jane. 2009. 'Literary Mashups Meet Tentacles. Has All Of Western Literature Been Leading Up To This.' io9. July 15. Online at: http://io9.com/5315301/literary-mashups-meet-tentacles-has-all-of-westernliterature-been-leading-up-to-this (consulted 10.09.2014).

Anderson, Sam. 2009. 'Sussex Chainsaw Massacre: The Horrification of Jane Austen', New York Review of Books, 6 September. Online at: http://nymag.com/arts/books/reviews/58847/ (consulted 10.09.2014).

[Anonymous]. 2016. 'Box office / business for Pride and Prejudice and Zombies (2016)'. IMDB.com. 28 February. Online at: http://imdb.com/title/tt1374989/business (consulted 21.05.2016). 
[Anonymous]. 2010. 'Wuthering Bites - A Review', Brontë Blog, 25 October. Online at: http://bronteblog.blogspot.com/2010/10/wuthering-bites-review.html (consulted 04.08.2015).

Austen, Jane. 2008. Pride and Prejudice [1813]. Rockville, Maryland: Arc Manor LLC.

Ayre, John. 1989. Northrop Frye: A Biography. Toronto: Random House.

Barthes, Roland. 1978. Image, Music, Text (trans. Stephen Heath). New York: Hill and Wang.

Binder, Heiko. 2009. 'Word of Mouth and Zombies'. Master of Publishing, Burnaby, British Columbia: Simon Fraser University. Online at: http://summit.sfu.ca/system/files/iritems1/9916/ETD4916.pdf （consulted 06.01.2015).

Boehm-Schnitker, Nadine, and Susanne Gruss (eds.). 2014a. Neo-Victorian Literature and Culture: Immersions and Revisitations. London: Routledge.

2014b. 'Introduction: Fashioning the Neo-Victorian - Neo-Victorian Fashions', in Boehm-Schnitker and Gruss (2014a): 1-17.

Bourriaud, Nicolas. 2009. Altermodern. London: Tate Publishing.

Bowman, Donna. 2009. 'Jane Austen and Seth Grahame-Smith: Pride And Prejudice And Zombies', The A.V. Club, 16 April. Online at: http://www.avclub.com/review/jane-austen-and-seth-grahame-smith-iprideand-prej-26559 (consulted 10.09.2014).

Braddon, M.E. 1896. 'Good Lady Ducayne', The Strand Magazine XI (Jan-Jun): 185199.

Carroll, Samantha J. 2010. 'Putting the 'Neo' Back into Neo-Victorian: The NeoVictorian Novel as Postmodern Revisionist Fiction', Neo-Victorian Studies 3(2): 172-205.

Colebrook, Claire. 2004. Irony. London: Routledge.

Collis, Clarke. 2009. "Pride and Prejudice and Zombies" Author Talks about His Literary Monster Mash-Up.' Entertainment Weekly. February 21. Online at: http://www.ew.com/article/2009/02/21/monster-mash-up (consulted 16.09.2015).

Cook, Nickolas, and Lewis Carroll. 2011. Alice in Zombieland. Chicago, Illinois: Sourcebooks.

Critchley, Simon. 2002. On Humour. London: Routledge.

Davies, Helen. 2015. Neo-Victorian Freakery: The Cultural Afterlife of the Victorian Freak Show. Houndmills, Basingstoke: Palgrave Macmillan.

Deahl, Rachel. 2009. 'Quirk Has Unlikely Hit with Jane Austen-Zombie Mash-Up', Publishers Weekly. 7 April. Online at: http://web.archive.org/web/20100302075649/http://www.publishersweekly. com/article/409276-

Quirk_Has_Unlikely_Hit_with_Jane_Austen_Zombie_Mash_up.php (consulted 12.04.2014).

De Groot, Jerome. 2016. Remaking History: The Past in Contemporary Historical Fictions. New York: Routledge.

Domsch, Sebastian. 2012. 'Monsters against Empire: The Politics and Poetics of NeoVictorian Metafiction in The League of Extraordinary Gentlemen', in Kohlke, Marie-Luise and Christian Gutleben (eds.), Neo-Victorian Gothic: 
Horror, Violence and Degeneration in the Re-Imagined Nineteenth Century. Amsterdam \& New York: Rodopi: 97-121.

Erwin, Sherri Browning, and Charlotte Brontë. 2010. Jane Slayre. New York: Gallery Books.

Erwin, Sherri Browning, and Charles Dickens. 2011. Grave Expectations. New York: Gallery Books.

Eshelman, Raoul. 2008. Performatism, or the End of Postmodernism. Aurora: The Davies Group Publishers.

Ferguson, Christine. 2011. 'Surface Tensions: Steampunk, Subculture, and the Ideology of Style', Neo-Victorian Studies 4(2): 66-90.

Gordillo, Gastón. 2014. 'The Killable Horde', Space and Politics, 3 September. Online at: http://spaceandpolitics.blogspot.ca/2014/09/the-killablehorde.html (consulted 12.09.2014).

Grahame-Smith, Seth. 2010. Abraham Lincoln, Vampire Hunter. New York: Grand Central Publishing.

Grahame-Smith, Seth, and Jane Austen. 2009. Pride and Prejudice and Zombies. Quirk Classics. Philadelphia, Pennsylvania: Quirk Books.

Gray, Sarah, and Emily Brontë. 2010. Wuthering Bites. New York: Kensington.

Grossman, Lev. 2009. 'Zombies Are the New Vampires' Time, 9 April. Online at: http://www.time.com/time/magazine/article/0,9171,1890384,00.html?imw= Y (consulted 10.09.2014).

Gunkel, David J. 2012a. 'Recombinant Thought: Slavoj Žižek and the Art and Science of the Mashup', International Journal of Žižek Studies 6(3). Online at: http://zizekstudies.org/index.php/ijzs/article/view/373/447 (consulted 15.02.2015).

2012b. 'What Does It Matter Who Is Speaking? Authorship, Authority, and the Mashup', Popular Music and Society 35(1): 71-91.

Gutleben, Christian. 2001. Nostalgic Postmodernism: The Victorian Tradition and the Contemporary British Novel. Amsterdam \& New York: Rodopi.

Halberstam, Judith. 1995. Skin Shows: Gothic Horror and the Technology of Monsters. Durham, North Carolina: Duke University Press.

Halford, Macy. 2009. 'Jane Austen Does the Monster Mash', The New Yorker, 4 April. Online at: http://www.newyorker.com/books/page-turner/jane-austendoes-the-monster-mash (consulted 04.08.2015).

Harvison, Anthony. 2009. "Pride and Prejudice and Zombies Review and Seth Grahame-Smith Interview." Den of Geek. June 11. Online at: http://www.denofgeek.com/books-comics/5872/pride-and-prejudice-andzombies-review-and-seth-grahame-smith-interview (consulted 16.09.2015).

Heilmann, Ann, and Mark Llewellyn. 2010. Neo-Victorianism: The Victorians in the Twenty-First Century, 1999-2009. New York: Palgrave Macmillan.

Hutcheon, Linda. 1995a. Irony's Edge: The Theory and Politics of Irony. London: Routledge. 1995b. The Politics of Postmodernism. London: Routledge.

2000. 'Irony, Nostalgia, and the Postmodern', in Vervliet, Raymond and Annemarie Estor (eds.), Methods for the Study of Literature as Cultural Memory, Textxet: Studies in Comparative Literature Series: Proceedings of the XVth Congress of the International Comparative Literature Association, 'Literature as Cultural Memory'. Amsterdam: Rodopi: 189-207. 
Hutcheon, Linda, and Mario J. Valdés. 2000. 'Irony, Nostalgia, and the Postmodern: A Dialogue', Poligrafías 3: 29-54.

Itzkoff, Dave. 2009. 'The Latest Jane Austen Mashup: "Sense and Sensibility and Sea Monsters", ArtsBeat (New York Times), 15 July. Online at: http://artsbeat.blogs.nytimes.com/2009/07/15/the-latest-jane-austenmashup-sense-and-sensibility-and-sea-monsters/?_r=0 (consulted 04.08.2015).

Jameson, Fredric. 1988. 'Postmodernism and Consumer Society', in Kaplan, Ann E. (ed.), Postmodernism and Its Discontents. New York: Verso: 192-205. 2010. Valences of the Dialectic. London: Verso.

Jen, Guy. 2010. 'Book Review: Jane Slayre', Geeks of Doom, 22 April. Online at: http://www.geeksofdoom.com/2010/04/22/book-review-jane-slayre (consulted 04.08.2015).

Kaufmann, Nicholas. 2009. 'Nothing New Under the Sun', The Internet Review of Science Fiction, 11 December. Online at: http://www.irosf.com/q/zine/article/10613 (consulted 04.08.2015).

Kellogg, Carolyn. 2009. "Pride and Prejudice and Zombies" by Seth GrahameSmith', BBC News. 4 April. Online at: http://www.latimes.com/entertainment/la-et-zombies4-2009apr04-story.html (consulted 14.09.2014).

Kenealy, Arabella. 1896. 'Some Experiences of Lord Syfret', The Ludgate 3: 35-46.

Kirby, Alan. 2009. Digimodernism: How New Technologies Dismantle the Postmodern and Reconfigure Our Culture. New York: Continuum.

Klipspringer, S.A., and F. Scott Fitzgerald. 2012. The Late Gatsby. Amazon.co.uk: Shay K. Azoulay.

Kohlke, Marie-Luise. 2014. 'Mining the Neo-Victorian Vein: Prospecting for Gold, Buried Treasure and Uncertain Metal'. In Boehm-Schnitker and Gruss (2014a): 21-37.

Lessig, Lawrence. 2008. Remix: Making Art and Commerce Thrive in the Hybrid Economy. London: Penguin.

Linstead, Stephen. 2002. 'Organizational Kitsch', 9 Organization (4): 657-682.

Lockyer, Sharon, and Michael Pickering. 2005. 'Introduction: The Ethics and Aesthetics of Humour and Comedy', in Lockyer, Sharon, and Michael Pickering (eds.), Beyond a Joke: The Limits of Humour. New York: Palgrave MacMillan: 1-24.

Lyall, Sarah. 2013. 'Pride, Prejudice, Promotion? Mr. Darcy Rising', The New York Times. 9 July. Online at: http://www.nytimes.com/2013/07/10/arts/design/pride-prejudice-promotionmr-darcy-rising.html (consulted 19.04.2015).

Mattin, David. 2012. 'Trendspotter: Mash-up Literature', The National (Arts \& Lifestyle). 3 September. Online at: http://www.thenational.ae/artsculture/books/trendspotter-mash-up-literature (consulted 02.09.2015).

McLeod, Kembrew, and Peter DiCola. 2011. Creative License: The Law and Culture of Digital Sampling. Durham, North Carolina: Duke University Press.

McNally, David. 2012. Monsters of the Market: Zombies, Vampires and Global Capitalism. Chicaco, IL: Haymarket Books.

Messina, Lynn, and Louisa May Alcott. 2010. Little Vampire Women. New York: HarperTeen. 
Mitchell, Kate. 2010. History and Cultural Memory in Neo-Victorian Fiction: Victorian Afterimages. Houndmills, Basingstoke: Palgrave Macmillan.

Moorat, A.E. 2009. Queen Victoria: Demon Hunter. London: Hodder \& Stoughton.

- 2010. Henry VIII: Wolfman. New York: Hodder \& Stoughton.

Moraru, Christian. 2013. 'Introduction to Focus: Thirteen Ways of Passing Postmodernism', American Book Review 24(4): 3-4.

Navas, Eduardo and Owen Gallagher (eds.). 2015. The Routledge Companion to Remix Studies. New York: Routledge.

Nealon, Jeffrey T. 2012. Post-Postmodernism: Or, the Cultural Logic of Just-in-Time Capitalism. Stanford, California: Stanford University Press.

Nelson, Camilla. 2013. 'Jane Austen ... Now with Ultraviolent Zombie Mayhem.' Adaptation 6(3): 338-354.

O'Keeffe, Alice. 2014. 'Sarah Waters: Interview', The Bookseller, 13 June. Online at: http://www.thebookseller.com/profile/sarah-waters-interview (consulted 06.08.2015).

Rekulak, Jason. 2009. 'How to Mash up Jane Austen and the Zombies', The Washington Post, 27 October. Online at: http://voices.washingtonpost.com/shortstack/2009/10/how_to_mash_up_jan e_austen_and.html (consulted 09.08.2015).

Rose, Margaret. 2009. 'Extraordinary Pasts: Steampunk as a Mode of Historical Representation', Journal of the Fantastic in the Arts, 20(3): 319-333.

Rousselot, Elodie (ed.). 2014. Exoticising the Past in Contemporary Neo-Historical Fiction. Houndmills, Basingstoke: Palgrave Macmillan.

Sadoff, Dianne F. and John Kucich. 2000. 'Introduction: Histories of the Present', in Kucich, John and Dianne F. Sadoff (eds.), Victorian Afterlife: Postmodern Culture Rewrites the Nineteenth Century. Minneapolis: University of Minnesota Press: ix-xxx.

Schuessler, Jennifer. 2009. 'Undead-Austen Mash-Ups', New York Times, 13 December. Online at: http://query.nytimes.com/gst/fullpage.html?res=9E05E3DC1E39F930A257 51C1A96F9C8B63\&ref=jane_austen (consulted 10.09.2014).

Schwarzbaum, Lisa. 2009. 'Pride and Prejudice and Zombies', Entertainment Weekly, 25 March. Online at: http://www.ew.com/article/2009/03/25/pride-andprejudice-and-zombies (consulted 04.08.2015).

Sinnreich, Aram. 2010. Mashed Up: Music, Technology, and the Rise of Configurable Culture. Amherst, Massachusetts: University of Massachusetts Press.

Sontag, Susan. 1969. Against Interpretation. New York: Dell.

Sonvilla-Weiss, Stefan (ed.). 2010. Mashup Cultures. New York: Springer.

Stamets, Bill. 2012. 'Black Venus: A Study in Exploitation', RogerEbert.com. 2 March. Online at: http://www.rogerebert.com/festivals-and-awards/blackvenus-a-study-in-exploitation (consulted 08.08.2015).

Stevens, Sam A. 2015. 'Book Review: Wuthering Bites by Sarah Gray (3/5)', Taking on a World of Worlds, 20 July. Online at: https://samannelizabeth.wordpress.com/2015/07/20/book-review-wutheringbites-by-sarah-gray-35/ (consulted 04.08.2015).

Sulmicki, Maciej. 2011. 'The Author as the Antiquarian: Selling Victorian Culture to Readers of Neo-Victorian Novels and Steampunk Comics.' Otherness: Essays \& Studies 2 (1): 1-16. 
Swinehart, Kirk Davis. 2010. "Review "Little Vampire Women," "Pride and Prejudice and Zombies" and "Abraham Lincoln: Vampire Hunter", Chicago Tribune, 27 October. Online at: http://www.chicagotribune.com/lifestyles/books/chibooks-review-mashups-story.html (consulted 04.08.2015).

Travers, Andrew. 1993. 'An Essay on Self and Camp', Theory, Culture and Society 10(1): 127-143.

Vermeulen, Timotheus, and Robin van den Akker. 2010. 'Notes on Metamodernism', Journal of Aesthetics \& Culture 2: 1-14.

Voigts-Virchow, Eckart. 2012. 'Pride and Promiscuity and Zombies, or: Miss Austen Mashed Up in the Affinity Spaces of Participatory Culture', in Nicklas, Pascal and Oliver Lindner (eds.), Adaptation and Cultural Appropriation: Literature, Film, and the Arts. Berlin: Walter De Gruyter: 34-56.

Winters, Ben H., and Jane Austen. 2009. Sense and Sensibility and Sea Monsters. Quirk Classics. Philadelphia, Pennsylvania: Quirk Books.

Winters, Ben H., and Leo Tolstoy. 2010. Android Karenina. Quirk Classics. Philadelphia, Pennsylvania: Quirk Books. 